\title{
ADOPTEES’ RIGHT TO SHARE IN TESTAMENTARY GIFTS AS "CHILDREN"
}

W

HERE A WILL CONTAINS A GIFT to the "children" of a named person, a question of construction arises with regard to the right of an adopted child to participate in the distribution. ${ }^{1}$ Where recognized, this right has been upheld on either or both of two grounds: (a) that the testator intended that he share in the gift, ${ }^{2}$ or (b) that adoption legally vested him with the status of a natural child..$^{3}$ Accordingly, where such intent is not readily inferable, the issue generally turns on the court's interpretation of the applicable adoption statute. ${ }^{4}$

\footnotetext{
${ }^{1}$ See generally 3 Page, Wills $\S$ ro23 (3d ed. 1941); 3 Powell, Real Property $\$ 357$ (1952); Oler, Construction of Private Instruments Where Adopted Children Are Concerned, 43 Mich. L. Rev. 705, $71 \mathrm{I}$ et. seq. (1945); and Notes, 70 A.L.R. 621 (1931), 144 A.L.R. 670 (1943).

${ }^{2}$ Fundamental to the law of wills is the proposition that the intent of the testator governs the distribution of his estate, unless contrary to law or public policy. ATKINson, Wills § 146 (2d ed. 1953); 2 PAGE, Wills, § 919 (3d ed. 1941). Where his intent can be ascertained from the language of the will itself; the will is controlling and no evidence is admissible in court to contradict or vary its terms. Fuller v. Nazal, 259 Ala. 598, 67 So.2d 806 (1953); Lytle v. Guilliams, 241 Iowa 523, 41 N.W.2d 668 (1951); Dennis v. Omaha Nat'l Bank, 153 Neb. 865, 46 N.W.2d 606 (1951); Cannon v. Cannon, 225 N.C. 6Ix, 36 S.E.2d 17 (1945); Industrial Trust Co. v. Davies, 74 R.I. 36,58 A.2d 399 (1948). Where the will contains a latent ambiguity, however, as to the property devised or the object of the testator's bounty, it is necessary for the court construing the will to place itself as nearly as possible in the position of the testator at the time he executed the will in order to determine his probable intent from a survey of the facts and circumstances which then existed and were known to him. Butts v. Trust Co. of Georgia, 209 Ga. 787, 75 S.E.2d 745 (1953); Davidson v. Davidson, 2 Ill.2d 197, 117 N.E.2d 769 (1954); Marks v. Thomas, 238 N.C. 544, $7^{8}$ S.E.2d 340 (1953); Noble v. Noble, 205 Okla. 91, 235 P.2d 670 (195I). 2 PAGE, Wills $\$ 920$ (3d ed. 194I). A testator is presumed to know the law in effect at the time the will was executed, and to have drawn the instrument in contemplation thereof. Cleveland Clinic Foundation v. Humphrys, 97 F.2d 849 (6th Cir. 1938); In re Heard's Estate, 107 Cal.App.2d 225, 236 P.2d 810 (1951); Barfield v. Aiken, 209 Ga. 483, 74 S.E.2d xoo (1953); Nelligan v. Long, 320 Mass. 439, 70 N.E.2d 175 (1946); Leeper v. Leeper, 347 Mo. 442, 147 S.W.2d 667 (1941); In re Tousey's Will, 260 Wis, 150,50 N.W.2d 454 (1951); 2 PAgE, Wills $\$ 925$ (3d ed. 194 I).

${ }^{3}$ See, e.g., In re Holden's Trust, 207 Minn. 211, 29 I N.W. 104 (1940); Haver v. Herder, 96 N.J. Eq. 554, 126 Atl. 661 (1924); In re Upjohn's Will, 304 N.Y. 366, 107 N.E.2d 492 (1952).

Adoption is purely statutory. In re Palmer, 129 Fla. 630, 176 So. 537 (1937); In re Jaren's Adoption, 223 Minn. 56r, 27 N.W.2d 656 (1947); Eggleston v. Landrum, 210 Miss. 645, 50 So.2d 364 (1951); Betz v. Horr, 276 N.Y. 83, II
} 
This is the problem which recently confronted the Supreme Court of North Carolina in Bradford v. Johnson.5 There, the testator had devised his property in separate trusts for the benefit of his twelve nephews and nieces during their lives. The will further provided that when a nephew or niece should die, the trust for his benefit should terminate and the corpus be divided per capita among the "children" of all the nephews and nieces. One of the nephews having died, the executor brought an action for a declaratory judgment to determine both the rights of a child adopted by another nephew fourteen years prior to the death of the testator and the rights of any child who might later be adopted by any of the nephews and nieces. ${ }^{6}$ The lower court held that, in both instances, the child would be entitled to share in the distribution of trust corpus. The supreme court, however, observed that the proper test of the adoptees' rights here was the intent of the testator-and that the adoption statute was irrelevant as it purported only to establish the right of adopted children to inherit through and from their adoptive parents. ${ }^{7}$ Accordingly, it reversed as to any child adopted after the testator's death, holding that the testator could not have contemplated that such a person should take; but it affirmed as to the child adopted before the testator's death, recognizing a presumption in his favor since the testator knew of his adoption in time to exclude him from the will but did not do so.

Early adoption statutes, with some exceptions, ${ }^{8}$ purported to estab-

N.E.2d 548 (1937); Wilson v. Anderson, 232 N.C. 212, 59 S.E.2d 836 (1950); In re Frazier, 180 Ore. 232, 177 P.2d 254 (1947). Since a testator is presumed to know the law, an argument can be made that the adoption statute controls the meaning of the word "child" as ambiguously used in the will. See text at note 26 infra. The effect of the statute on a will is a matter for court interpretation. See Oler, $o p$. cit. supra note I, at 715 et. seq.

${ }_{237}$ N.C. 572,75 S.E.2d 632 (1953).

${ }^{0}$ The right of a child adopted by a grandniece to take her share by representation was also in issue. As to this child the question was decided in the negative, as the will provided that the "issue" of any deceased parent should represent that parent per stirpes. $I d$. at $58 \mathrm{I}, 75$ S.E.2d at 638 . The question of whether adopted children are "issue" is outside the scope of this Note.

${ }^{7} 237$ N.C. $572,578,75$ S.E.2d 632,636 (1953). See N.C. Gen. STAT. $§ 48-23$ (Supp. 1953): "The final order [of adoption] forthwith shall establish the relationship of parent and child between the petitioners and the child, and, from the date of the signing of the final order of adoption, the child shall be entitled to inherit real and personal property from the adoptive parents in accordance with the statutes of descent and distribution [N.C. GEN. STAT. $\$ \S 29-149$ (10), 29-I(14) (1950)].”

${ }^{8}$ E.g., ACrS AND Resolves of Mass. c. 3 10 (1871), first enacted in 1851 , stated that an adopted child was the equivalent of a natural legitimate child in all instances except two which are not relevant here. ACTS AND Resolves of MAss. c. 213, § 9 (1876), however, limited the effect of adoption by allowing the adoptee to take if the 
lish the parent-child relationship only as between the parties to the adoption. ${ }^{9}$ These statutes gave an adopted child the right of inheritance from his adoptive parents alone and were construed not to accord him the right of inheritance from their ancestors. ${ }^{10}$ By the same token, he was held not to have been conferred with the right to take as a "child" of his adoptive parents under the wills of other persons. ${ }^{11}$ Later revisions of the adoption statutes in some jurisdictions, however, have tended to liberalize the effect of adoption and do away with the vestigial distinctions between adopted and natural children. ${ }^{12}$ Thus, many statutes now proclaim that adopted children are to be deemed natural, legitimate children "for all legal consequences" "for every purpose," or "for all intents and purposes."15 Others are more specific and expressly include as an incident of adoption the right to share as "children" under class gifts in wills. ${ }^{\mathbf{1 6}}$

The prevailing view seems to be that an adoption statute can have no effect on the construction of a will. ${ }^{\mathbf{1 7}}$ Instead, a subjective intent has

testator was the adoptive parent, but established a presumption against the adoptee where the testator was not his parent. Tirrell v. Bacon, 3 Fed. 62 (C.C. Mass. 1880 ).

'E.g., Cal. Civ. Code $\$ 228$ (Deering 1949); ConN. Gen. StAT. $§ 6869$ (1949); D.C. CODE § 16-205 (1940); IND. STAT. ANN. § 3-121 (Burns Replacement 1946); ME. Rev. Stat. c. $145, \S 38$ (1944); Mich CoMp. L. $\$ 27.317 \$$ (1948); N.C. GeN. STAT. § 48-23 (Supp. r953); W.VA. CodE $\$ 4759$ (Michie 1949). See generally Oler, op. cit. supra note 1 , at 715 et. seq.

${ }^{10}$ In re Stewart's Estate, 30 Cal.App. 594, 86 P.2d 1071 (1939); Brunton v. Internat'l Trust Co., II4 Colo. 298, 164 P.2d 472 (1945); Woods v. Crump, 283 Ky. 675, 142 S.W.2d 680 (1940); Allen v. Nickerson, 293 Mass. 136, 199 N.E. 482 (1936); Crawford v. Arends, 351 Mo. 1100 , I76 S.W.2d I (x943); In re Hodges' Will, 294 N.Y. 58, 60 N.E.2d 540 (1945); Grimes v. Grimes, 207 N.C. 778, I78 S.E. 573 (1935).

${ }^{11}$ In general, there is a presumption that the testator intended that his own adoptees take as "children," but not children adopted by others. See Brunton v. Internat'l Trust Co., II4 Colo. 298, I64 P.2d 472 (I945); Brookins v. Citizens \& Southern Nat'l Bank, 205 Ga. 128, 52 S.E.2d 46r (1949); McLeod v. Andrews, 303 Ky. 46, I96 S.W.2d 473 (1946); In te Chapple's Estate, 338 Mich. 246, 61 N.W.2d 37 (1953); In re Yates' Estate, 28 × Pa. 178, 126 Atl. 254 (1924).

${ }^{12}$ See, e.g., 12 DeL. CODE ANN. $\$ \S 9$ 919-20 (1953); IOWA CODE ANN. $\$ 600.6$ (1950); Minn. Stat. ANN. \$259.07 (1947); N.J. Stat. ANn. § 9: 3-9 (1953).

${ }^{13}$ Ky. Rev. Stat. $\$$ I99.530(2) (1953); N.D. REv, Code \$ 14-II13 (1943).

${ }^{14}$ Mo. Stat. ANn. $\$ 453.090$ (Vernon 1952); Tex. Civ. Stat. AnN. art. 46(a), \& 9 (Vernon I947).

${ }^{18}$ Ala. Code tit. 27, $\$ 5$ (1940); Colo. Rev. Stat. c. 4, $\$$ II (1953); Ohio Rev. CODE $\S 3107.13$ (1954); R.I. GEN. LAwS ANN. c. $420, \S 6$ (1938); Wis. STAT. $\S$ 322.07 (1947).

${ }^{10}$ Ga. Code ANN. $\S 74-414$ (Supp. I95I) ; Ill. Rev. Stat. c. 4, art. 4, § I (1951); MD. Code AnN. art. I6, $\$ 86$ (Flack I95I); N.Y. Dom. Rel. Law $\$$ I I5 (1954); Pa. Stat. ANn. tit. 20, $\$$ I80.14 (Purdon 1950).

${ }^{17}$ Noreen v. Sparks, 103 F. Supp. 588 (D.D.C. I 952); Russell v. Russell, 84 Ala. 
been "found," or ascribed to the testator, by the court, without reference to the statute, and this has commonly been presumed to have been that the testator did not regard children adopted by others as their "children" for this purpose. ${ }^{18}$ It would appear, however; that courts can confidently adhere to this view only in those jurisdictions whose adoption statutes do not clearly purport to elevate adopted children in all respects to the status of natural children ${ }^{19}$-and their number is fast dwindling. Eleven such states have recently revised their adoption statutes so as to equate the legal status of the adopted child more closely with that of the natural child; ${ }^{20}$ and while these revisions have, thus far, been held only to have no retroactive effect, ${ }^{21}$ there have been indications that courts will effectuate their underlying policy in resolving ambiguities in future wills. ${ }^{22}$

Even absent these liberalizing revisions, however, courts in several other states have taken the view that, since the testator is presumed to have known the law, the adoption statute in effect at the time the will

48, 3 So. 900 (I888); In re Pierce's Estate, 32 Cal.2d 265, 196 P.2d I (I948); Brunton v. Internat'l Trust Co., 114 Colo. 298, I64 P.2d 472 (I945); Brookins v. Citizens \& Southern Nat'l Bank, 205 Ga. 128, 52 S.E.2d 461 (1949); Blackford v. Barnhill, 119 Ind.App. 257, 84 N.E.2d 64 (1949); Mesecher v. Lier, 24 I Iowa 818 , 43 N.W.2d 149 (1950); Savells v. Brown's Guardian, 187 Ky. 134,218 S.W. 462 (1920); In re Woodcock, 103 Me. 214, 68 Atl. 82 I (1907); Eureka Life Ins. Co. v. Geis, I21 Md. 196, 88 Atl. 158 (1913); In re Chapple's Estate, 338 Mich. 246, 61 N.W.2d 37 (1953); Melek v. Curators of Univ. of Missouri, 2 I3 Mo.App 572, 250 S.W. 6r4 (1923); In re Yates' Estate, 281 Pa. 178, 126 Atl. 254 (1924); Rhode Island Hospital Trust Co. v. Sack, 79 R.I. 493, 90 A.2d 436 (x952); Harle v. Harle, 109 Tex. 214, 204 S.W. 317 (I918); Lichter v. Thiers, 139 Wis. 48 I, I21 N.W. 153 (1909).

${ }^{18}$ See cases cited note 1 I supra.

${ }^{10}$ No case has been found in which a court adhered to this view in the face of a liberal adoption statute.

${ }^{20}$ Kentucky has the "for all legal consequences" statute (note 13 supra). Alabama, Colorado, Rhode Island, and Wisconsin have the "all intents and purposes" type (note 15 supra). Missouri and Texas have the "for every purpose" type (note 14 supra). Georgia, Maryland, and Pennsylvania statutes contain the express recognition of the right to take under a will as a "child" (note I6 supra). Iowa Code Ann. \$600.6 (1946), states that "upon the entering of [final adoption] decree, the rights, duties, and relationships between the child and parents by adoption shall be the same that exist between parents and child by lawful birth. . .."

${ }^{21}$ Copeland v. State Bank, 300 Ky. 432, 188 S.W.2d ror7 (x945); Gutman v. Safe Deposit \& Trust Co. of Baltimore, I98 Md. 39, 81 A.2d 207 (195I); In re Corr's Estate, $338 \mathrm{~Pa} .337$, 12 A.2d 76 (1940).

22 Barfield v. Aiken, 209 Ga. 483, 74 S.E.2d 100 (1953) (reiterating presumption that testator intends his property to go where law carries it); Leeper v. Leeper, 347 Mo. 456 , 147 S.W.2d 667 (1941) ("children" defined by statute in force at time instrument was executed); cf. Russell v. Russell, 84 Ala. 48, 3 So. 900 (r888) (narrow statute in force determined whether adoptee was a "child"). 
was executed is a circumstance bearing on his intent, although of no greater significance than any other circumstance. ${ }^{23}$ The fact that the testator was a stranger to the adoption or that it occurred after his death, however, has generally been held to negate any inferences of intent which may arise from the statute. ${ }^{24}$

A few other jurisdictions, on the other hand, have now taken the view that where the statute is broad enough to give adopted children the full legal status of natural children, ${ }^{25}$ it controls in the absence of a clear indication of contrary intent by the testator. ${ }^{26}$ This view, which creates a presumption that the testator intended that children adopted by others should be regarded as "children" for this purpose, is exactly antithetical to the traditional view. ${ }^{27}$ Paradoxically, however, despite a strong case to the contrary, ${ }^{28}$ this rule has generally been held inapplicable where the testator did not know of the adoption or where it occurred after his death. ${ }^{29}$

The decision in the Bradford case as to any child adopted after the testator's death would therefore seem to be in accord with current authority $;^{30}$ the decision as to the child adopted within the testator's lifetime, however, is quite advanced and liberal and represents at least

\footnotetext{
${ }^{23}$ Morgan v. Keefe, ${ }_{35}$ Conn, 254, 63 A.2d 148 (1948); Wheeling Dollar Saving and Trust Co. v. Stewart, 128 W.Va. 703, 37 S.E.2d 563 (1946). This view is also adhered to in several jurisdictions which have more liberal statutes. See, e.g., Hall v. Crandall, 25 Del.Ch. 339, 20 A.2d 545 (1941); Munie v. Gruenewald, 289 IIl. 468, I24 N.E. 605 (I9I9); Third Nat'l Bank v. Davidson, 157 Ohio St. 355, 105 N.E.2d 573 (i952).

${ }^{24}$ See, e.g., Belfield v. Findlay, 389 Ill. 526, 60 N.E.2d 403 (1945) and cases cited in note 23 supra.

${ }^{25}$ See notes $12-16$ supra and accompanying text.

${ }^{26}$ In re Holden's Trust, 207 Minn. 2 II, $29 \mathrm{I}$ N.W. IO4 (1940); Haver v. Herder, 96 N.J. Eq. 554, I26 Atl. 66I (1924); In re Fisler's Estate, 13 I N.J. Eq. 310, 25 A.2d 265 (1942); In re Upjohn's Will, 304 N.Y. 366, 107 N.E.2d 492 (1952). Accord, Leeper v. Leeper, 347 Mo. 456, I47 S.W.2d 667 (194r); Hoellinger v. Molzhon, 77 N.D. I08, 4 I N.W.2d 217 (1950).

${ }^{27}$ I.e., that the statute has no effect on the construction of the will and that the testator is presumed not to intend children adopted by others to take as their "children." See note II supra and accompanying text.

${ }^{28}$ See In re Holden's Trust, 207 Minn. 2 II, $29 x$ N.W. I04 (I940).

${ }^{29}$ See In re Fisler's Estate, 131 N.J. Eq. 310, 25 A.2d 265 (1942); Ahlemeyer v. Miller, I02 N.J.L. 54, 131 Atl. 54 (1925); In te Hall's Will, 127 N.X.S.2d 445 (1954).

${ }^{39}$ See, e.g., Comer v. Comer, 195 Ga. 79, 23 S.E.2d 420 (1942); Belfield v. Findlay, 389 Ill. 526, 60 N.E.2d 403 (1945); Sanders v. Adams, 278 Ky. 24, 128 S.W.2d 223 (1939); In re Corr's Estate, 338 Pa. 337, 12 A.2d 76 (1940); Cochran v. Cochran, 43 Tex. Civ. App. 259, 95 S.W. $73 \mathrm{I}$ (1906); and cases cited in notes 23 and 29 stpra.
} 
a partial abandonment of the long-held traditional position. ${ }^{31}$ The significance of this shift is heightened by the fact that North Carolina has followed the recent liberal trend to a point beyond that reached by other states under their more modern statutes ${ }^{32}$ although its statute was expressly held by the court to be too limited to conduce to this end. However, where the testator either did not know of the adoption or did not have time in which to change his will, the implication seems to be that no presumption of testamentary intent will be created in favor of an adopted child. ${ }^{33}$ Accordingly, in order to protect the advance made by the Bradford decision and further extend it, it would appear to be desirable to enact legislation which would unequivocally define the rights of adopted children under testamentary dispositions. ${ }^{34}$

$$
\text { John D. Johnston, JR. }
$$

${ }^{31}$ In Smyth v. McKissick, 222 N.C. 644, 24 S.E.2d 621 (I922), the court held, on substantially similar facts, that the evidence adduced on behalf of the adopted child (i.e., that the testator knew and approved of the adoption and treated the natural and adopted children alike) was sufficient to overcome the presumption against him and to establish an intent on the part of the testator that he should take. The Bradford case, on the other hand, holds that the presumption is in favor of the adopted child.

${ }^{32}$ The Bradford decision is the only one to recognize such a presumption in the face of a narrow statute (see cases cited in note I7 supra). The rule is also more liberal than that laid down in the cases holding that a broad statute is only a circumstance (see note 23 supra).

${ }^{33}$ In Wachovia Bank v. Green, 239 N.C. 6I2, 80 S.E.2d 77I (1954), where the children were adopted after the testator's death, the court held that the Bradford rule did not apply and found in the will an intent to exclude adopted children.

${ }^{36}$ It is understood that legislation equating the status of natural and adopted children to the extent of including the right to take as "children" under class gifts of wills is now before the North Carolina General Statutes Commission. 
